\title{
Dansk Idræts Forbund og forholdet til Tyskland 1940-45
}

\author{
af Steen Rasmussen
}

Vinteren 1939-40 herskede der krigstilstande flere steder i Europa. Dette betød naturligvis usikre forhold på mange områder, og Dansk Idræts Forbund (DIF) tog da også sit samarbejde med krigsførende nationer op til overvejelse. På baggrund af Danmarks neutralitet besluttede DIF, i fuld overensstemmelse med de danske myndigheder, at bibeholde de internationale forbindelser, også med lande der var i krig. Man var indstillet på at fastholde trufne aftaler om idrætsstævner, og ligeledes fortsætte med at indgå sådanne, også selv om arrangementerne blev afholdt i krigsførende lande, et standpunkt der faldt i god tråd med de fleste andre nationers. Dansk idræt havde som følge truffet en del aftaler om landskampe og stævner for foråret 1940, bl.a. med Tyskland, da den tyske indmarch i Danmark d. 9. april 1940 pludselig ændrede situationen. Den tyske besættelse af landet betød ikke, at vi kom i krig med Tyskland. Officielt var der tale om en fredsbesættelse, hvor Tyskland lovede, at de ikke havde til hensigt at anfægte Danmarks territoriale integritet og politiske uafhængighed. Den danske regering protesterede naturligvis, men accepterede at der ikke herskede nogen krigstilstand mellem de to lande. De var villige til forhandling med tyskerne, med det mål at føre Danmark så uskadt som muligt gennem krigen. Regeringens synspunkt var, at alle forhandlinger og kontakter måtte gå den normale vej, dvs. gennem det danske udenrigsministerium, for på den måde blev det understreget, at der formelt var tale om en forbindelse mellem to suveræne stater.

Regeringens retningslinier til befolkningen lød på, de skulle optræde roligt og behersket og undgå uoverlagte handlinger, hvilket i det store hele blev fulgt. Tyskerne mærkede vel kun sjældent imødekommenhed, men heller ikke ofte direkte fjendtlighed; skulderen var endnu kun afkølet et par grader.

Den ændrede situation kunne naturligvis ikke undgå at få konsekvenser for idrætten. Dels opstod der en del praktiske problemer på grund af tysk beslaglæggelse af idrætsfaciliteter til militære formål, dels stod en del forbund over for nært forestående arrangementer, bl.a. med Tyskland. For Dansk Amatør Bokse Union (DABU) var problemet højst aktuelt, idet Danmark skulle møde Tyskland i en bokselandskamp d. 12. april. Efter henstilling 
fra DIFs formand valgte DABU at udsætte kampen. At man valgte denne løsning og ikke aflyste kampen, giver et udmærket indtryk af stemningen inden for idrætskredse umiddelbart efter d. 9. april. Ganske vist var man usikker på fremtiden, men man regnede med, at idrætten kunne fortsætte nogenlunde uanfægtet, også med hensyn til det internationale samarbejde.

I DIFs øverste ledelse gjorde man sig naturligvis visse overvejelser omkring fremtiden. For det første mente man, at det var yderst vigtigt at bevare kontrollen over dansk idræt, og forhindre enhver form for tysk indblanding $i$ idrættens interne forhold. For det andet var der problemet omkring forholdet til tysk idræt og internationalt samarbejde $i$ almindelighed. På den ene side var både bestyrelsen og forretningsudvalget enige om, at man ikke på nuværende tidspunkt kunne fortsætte samarbejdet med Tyskland. På den anden side ønskede man ikke at provokere besættelsesmagten unødigt, og dermed risikere en tysk indblanding i dansk idræts interne forhold. DIF besluttede at løse problemet ved at standse sit samarbejde med alle krigsførende nationer, hvilket jo ikke ville isolere DIF fra internationalt samkvem, da der på dette tidspunkt var mange nationer, som ikke direkte var involveret $\mathrm{i}$ krigen. Håbet om at opretholde forbindelser til udlandet, på trods af bruddet med Tyskland, blev slukket af det danske udenrigsministerium. Inden offentliggørelsen af DIFs beslutning forlangte ministeriet, at ordet krigsførende blev ændret til udlandet, hvilket medførte en helt ny situation. Ingen i DIFs øverste organer havde forestillet sig den mulighed, at beslutningen kunne komme til at omfatte de neutrale lande, som fx Sverige. DIFs formand, Castenschiold, accepterede modvilligt det nye indhold, og få timer efter blev pressen orienteret om, at Danmark d. 17. april havde standset alt idrætssamarbejde med udlandet. Meddelelsen lød:

„Som situationen nu er i verden, har Dansk Idræts Forbunds bestyrelse på et møde d. 15. april 1940 vedtaget at henstille til specialforbundene, at idrætsudøvere fra udlandet indtil videre ikke skal have tilladelse til at konkurrere i Danmark, og at der ligeledes indtil videre ikke gives danske idrætsudøvere licens til konkurrencer i udlandet. Dette gælder også opvisninger.

Bestemmelsen træder straks i kraft."

Samtidig meddelte udenrigsministeriet pressen, at beslutningen ikke måtte kommenteres. Det var åbenlyst, at hverken DIF eller ministeriet ønskede for megen postyr omkring beslutningen.

DIFs håb om at beslutningen ikke ville vække større opsigt hos besættelsesmagten, da den i sin endelige form ikke fremstod som specielt rettet mod Tyskland, blev hurtigt gjort til skamme. Allerede et par dage efter forbudets 
offentliggørelse mødte den tyske gesandt Renthe-Fink personligt op i udenrigsministeriet, hvor han til direktør Mohr udtrykte sin store utilfredshed med DIFs beslutning. På trods af Mohrs forklaringer om at ministeriet fuldt ud støttede beslutningen, forlangte gesandten snarest et møde med Castenschiold. Dette møde kom i stand allerede d. 29. april, og blev efter Mohrs foranledning afholdt i udenrigsministeriet, hvilket viser, at man her så ganske alvorligt på sagen. På mødet gjorde det tyske gesandtskab sig alle mulige anstrengelser for at overbevise Castenschiold om, at DIF skulle ophæve forbudet. Castenschiold fastslog dog, at DIF ikke ville fravige sin nuværende linie, med mindre det skete under pres fra tysk side, og mødet sluttede resultatløst.

At det tyske gesandtskab viste en så stor interesse for en normalisering af idrætssamkvemmet mellem Danmark og Tyskland, måtte skyldes to ting. For det første at man fra tysk side nærede et vist håb om, at dansk-tyske idrætsarrangementer kunne være med til at gøre den danske befolkning mere positiv over for Tyskland, hvilket ville være et resultat det tyske udenrigsministerium kunne bruge i sin interne magtkamp med den tyske værnemagt. At der før besættelsen eksisterede en stor beundring for tysk idræt, både inden for DIFs ledelse og i befolkningen, var ikke nogen hemmelighed. For det andet at et normalt dansk internationalt idrætssamarbejde ville være med til at vise omverdenen, at der ikke var tale om nogen krigerisk besættelse af Danmark, forholdet mellem de to lande var udmærket.

At den tyske henvendelse kom på et så tidligt tidspunkt, hvor meget endnu var usikkert, og hvor linierne for det fremtidige politiske forhold mellem de to lande stadig var uklare, kan godt virke lidt overraskende. Man kunne forvente, at der var andre og vigtigere ting, der skulle bringes i orden før idrætssamarbejdet, men fra tysk side har man åbenbart prioriteret idrættens propagandaværdi højt.

På baggrund af DIFs apolitiske karakter og den apolitiske holdning, en stor del af publikum indtog, når det gjaldt idræt, er det sandsynligt, at gesandtskabet har betragtet idrætten som et udmærket sted at sende de første følere ud, når det drejede sig om en tilnærmelse mellem de to lande. Risikoen for at idrætsarrangementer ville få ubehagelige konsekvenser for besættelsesmagten, vurderede gesandtskabet selv som minimal. I alle tilfælde ville en henvendelse være uskadelig, da man næppe kunne forvente, at en sådan ville få DIF til at foretage sig yderligere forholdsregler.

For både Castenschiold og Leo Frederiksen stod det klart, at sagen langtfra var afsluttet, og at man måtte forvente yderligere udspil fra tysk side den kommende tid. For at forebygge et eventuelt tysk pres på de enkelte specialforbund, kontaktede Castenschiold de forskellige formænd, for at 
pointere, at forbudet gjaldt ethvert samarbejde med tyskerne.

Det tyske udspil lod ikke vente længe på sig, og det var især fodbolden, der var i tyskernes søgelys, hvilket sandsynligvis hang sammen med, at fodboldens forholdsvis store tilskuertal var et udmærket udgangspunkt til at styrke propagandaeffekten. I de byer hvor der befandt sig tyske tropper, var det desuden den idrætsgren, hvor det var nemmest at arrangere kampe mellem tyske soldater og lokale danske hold. De tyske forsøg på at få et samarbejde i gang bevægede sig også på to niveauer. Dels på det øverste officielle, henvendelser fra det tyske fodboldforbund til DBU, dels på det nederste niveau i den danske fodboldstruktur, klubberne, hvor værnemagten meget tidligt prøvede at få lokale klubber til at spille mod tyske soldater på stedet.

På det officielle plan gik det forholdsvis nemt med at udskyde samarbejdet, idet man blev enige om at udsætte alle forhandlinger til efteråret 1940, hvor man så skulle mødes igen. På det lokale plan arbejdede man anderledes intenst fra tysk side. I begyndelsen af maj måned 1940 lykkedes det at få arrangeret en kamp i Holstebro mellem et lokalt hold og soldater fra værnemagten. Kampen blev imidlertid aflyst i sidste øjeblik, da DBUs repræsentant på stedet nedlagde forbud mod, at den blev gennemført. Dette vakte stor utilfredshed hos den tyske kommandant $\mathrm{i}$ området, en utilfredshed der var så kraftig, at man blev bekymret i det danske udenrigsministerium. Kontorchef Eskelund fra ministeriet kontaktede Castenschiold for at høre, om det virkelig var rigtigt, at sådanne kampe også var omfattet af forbudet. For første gang spores en vis usikkerhed hos Castenschiold, der ikke mente, at det kunne være tilfældet, da forbudet, efter hans opfattelse, ikke var til hindring for tysk deltagelse $\mathrm{i}$ de daglige idrætsaktiviteter, og med hensyn til lokale kampe mellem tyske og danske kunne DBU næppe forhindre, at de fandt sted, og i øvrigt havde man heller ikke noget imod det, sålænge de blev gennemført på en rolig og stilfærdig måde. Det var det ydre apparat omkring fodboldkampe, så som musik og andre mere eller mindre nationale tilkendegivelser, man forbød. Denne fortolkning lod Castenschiold gå videre til Eskelund, der blev synligt beroliget og straks ville orientere den tyske kommandant.

De andre specialforbund blev ikke orienteret om denne fortolkning af forbudet, og inden for den tyske værnemagt var man heller ikke klar over, eller i hvert fald lod man som om, man ikke var klar over denne nye fortolkning. Der herskede stadig utilfredshed over forholdene inden for den tyske kommandomyndighed i Jylland, hvilket gjorde stabschefen for den danske-jyske division, kaptajn Sabroe, urolig. I en samtale mellem ham og Castenschiold d. 24. maj 1940 henstillede han, at man ophævede DBUs forbud, da han anså det for at være årsag til gnidninger mellem værnemagten og befolkningen. Castenschiold redegjorde for DBUs nye fortolkning, og 
kaptajn Sabroe mente, at dette muligvis ville klare sagen, men fandt det klogest at Castenschiold talte med DBU og forklarede, hvor alvorlig situationen var. Allerede samme dag mødtes Castenschiold og Leo Frederiksen for at drøfte, hvad man skulle gøre. De blev enige om, at en udførligere fortolkning af forbudet var nødvendig, således at DIF over for tyske klager kunne henvise til, at man fra forbundets side havde gjort, hvad man kunne for at undgå vanskeligheder. De var enige om, at DBU skulle komme med udspillet, og derefter skulle den nye fortolkning gives videre til de andre specialforbund. Både Castenschiold og Leo Frederiksen var interesserede i en hurtig og smertefri afvikling af sagen, således at både DIF og DBU kunne stille sig uden for ansvar, hvis der kom nye tyske eller danske klager over modvilje mod idrætssamkvem.

DBU udsendte sit cirkulære d. 27. maj 1940, og fra nu af var det tilladt at spille uofficielle fodboldkampe mod tyske hold, bare de ydre rammer var yderst beskedne. Samtidigt blev det tilkendegivet, at det var tilladt tyske soldater at træne i danske klubber, hvilket skete i begrænset omfang.

Cirkulæret var et klart brud med den hidtidige førte politik, selv om det blev hævdet, at det hele tiden havde været meningen, at forbudet kun gjaldt officielt samkvem. De intentioner der lå bag DIFs beslutning af 15. april, var jo netop at forhindre ethvert samkvem med tyskere og Tyskland, et mål som alle i DIFs bestyrelse var enige om.

Kort tid efter besluttede DIFs forretningsudvalg at ophøje DBUs fortolkning til DIFs officielle standpunkt. I DIFs bestyrelse kom det aldrig til nogen afstemning, Castenschiold nøjedes med at orientere medlemmerne om den nye holdning. Kun et medlem, Ernst Petersen fra Odense, kritiserede beslutningen, og fremhævede at idrætssamkvemmet var en brik i et større politisk spil fra tysk side. Dette blev skarpt afvist af Castenschiold, og mødet bar tydeligt præg af, at man ikke var interesseret $\mathrm{i}$ en debat om årsagerne til - og konsekvenserne af den nye fortolkning.

Det må fremhæves, at fortolkningen stillede dansk idræt i en paradoksal situation, der var svær at forklare over for offentligheden. På den ene side var der forbud mod officielle arrangementer med udenlandsk deltagelse, på den anden side kunne udlændinge godt deltage i arrangementer, bare de ikke blev opreklameret som kampe mellem danske og udenlandske idrætsfolk. Da sådanne arrangementer sandsynligvis allerede havde fundet sted og måtte være forløbet stille og roligt, kan man godt få den tanke, at Castenschiold så fortolkningen som en forholdsvis omkostningsfri gestus, hvorved DIF kunne skabe sig lidt good-will hos besættelsesmagten. Samtidigt kunne forbundet håbe på, at indrømmelsen ville tilfredsstille gesandtskabet $i$ en sådan grad, at det tyske pres ville aftage, og at de måske ikke ville gå videre med deres ønske om total ophævelse af forbudet. 
Det var et ,fait accompli“ bestyrelsen blev stillet over for, helt i strid med den normale procedure, men spørgsmålet er om bestyrelsen overhovedet havde nogen reel valgmulighed. DBU havde jo allerede udsendt sit cirkulære, og forskellige myndigheder - såvel danske som tyske - var bekendt med dets indhold. En afvisning ville have svækket forbundet både indadtil og udadtil. Desuden ville det have været uhyre vanskeligt, for ikke at sige umuligt, at forklare gesandtskabet, hvorfor nogle klubber kunne have samkvem, når andre ikke kunne. Trak DBU sin fortolkning tilbage, ville det fra tysk side blive opfattet som en handling rettet mod dem, og derved forvære forholdet mellem DIF og besættelsesmagten. Dette var således en dårlig løsning, hvis konsekvenser DIF absolut ikke var interesseret $i$ at blive konfronteret med.

Den nye fortolkning tilfredsstillede på ingen måde besættelsesmagten, og der kan spores en stigende bekymring i det danske udenrigsministerium, efterhånden som det viste sig, hvor interesserede tyskerne var i at få normaliseret idrætssamarbejdet. Renthe-Fink drøftede flere gange sagen med udenrigsminister P. Munch, dog uden konkrete følger. Den 7. juni henvendte gesandten sig skriftligt til $P$. Munch, og bad ham om at bruge sin indflydelse til at få DIF til at ophæve forbudet totalt. Hans begrundelse var, at forbudet hovedsagligt var rettet mod det dansk-tyske idrætssamkvem, hvilket betød, at det var en belastning for det dansk-tyske forhold. Endvidere påstod han, at det tyske gesandtskab havde modtaget flere henvendelser fra begge sider, om at man ønskede samarbejdet genoptaget.

Både for DIF og ministeriet var sagen ved at blive yderst alvorlig, og det var klart, at hvis DIF skulle opretholde forbudet, måtte man være sikker på ministeriets fulde støtte. Der blev aftalt et nyt møde mellem DIF og gesandtskabet, men forinden krævede Castenschiold en klar stillingtagen fra ministeriets side. DIF var rede til at opretholde forbudet indtil efteråret 1940, hvis ministeriet ønskede det, men forudsætningen var ministeriets officielle støtte. Ministeriet var meget tilbageholden, og under en samtale mellem Castenschiold og Mohr inden mødet med gesandtskabet, fremgik det klart, at ministeriet forventede, at DIF ville blive nødt til at ændre standpunkt i nær fremtid. Det eneste råd man ville give DIF var, at man, hvis det blev aktuelt, startede med kampe mod andre nationer end Tyskland, fx ville Sverige være velegnet til en sådan blød start. Ellers foretrak ministeriet at gå i venteposition og afvente det nært forestående møde. For ministeriet var det overordnede spørgsmål på dette tidspunkt, hvorledes et eventuelt idrætssamarbejde med Tyskland ville blive modtaget $i$ idrætskredse. Var de negative, ville en ophævelse fungere stik modsat sin hensigt, da det i så fald ville være en yderligere belastning for det dansk-tyske forhold.

På mødet d. 27. juni mellem DIF og gesandtskabet blev DIF, repræsenteret ved Castenschiold og Leo Frederiksen, og det danske udenrigsministerium 
udsat for et voldsomt tysk pres, hvor Renthe-Fink bl.a. spillede på, at et idrætssamarbejde ville gøre den danske befolkning mere positivt stemt over for Tyskland. På trods af tyskernes skarpe tone, fastholdt DIF den nye fortolkning, længere kunne man ikke strække sig. Situationen var kritisk, da Leo Frederiksen fremkom med et nyt forslag. Han skulle snart have et møde med det svenske fodboldforbund, som var meget interesserede i at genoptage samarbejdet med Danmark. Når dette møde var overstået, skulle man påny drøfte situationen med tyskerne, hvilket gesandtskabet accepterede.

Under mødet havde gesandtskabet flere gange antydet, at større kredse inden for dansk idræt var interesserede i at få forbudet hævet. Hvorvidt dette er sandt, er svært at afgøre, men under alle omstændigheder såede det tvivl i Castenschiolds sind om specialforbundenes reelle ønsker. Samtidigt mærkede han, hvorledes den politiske støtte begyndte at skride væk under hans fødder, og efter Scavenius's tiltrædelse som udenrigsminister d. 8. juli 1940, måtte han se i øjnene, at det nu ville blive endnu vanskeligere at bibeholde den smule støtte, han havde fra ministeriet, hvis det tyske gesandtskab fastholdt sit standpunkt.

Den 12. juli kom Leo Frederiksen hjem fra Sverige og medbragte to datoer for landskampe mod Sverige, d.. 6. oktober i Sverige og d. 20. oktober i København. Dette betød efter Leo Frederiksens opfattelse, at en landskamp mod Tyskland først kunne finde sted i begyndelsen af november, hvilket passede fint ind i det mønster, man tidligere havde været sporadisk inde på, først mod Sverige siden mod Tyskland, et mønster som Renthe-Fink selv gik ind for. Castenschiold og Leo Frederiksen blev enige om at indkalde til bestyrelsesmøde d. 5. august for at diskutere en ophævelse af forbudet.

Inden bestyrelsesmødet afholdt Castenschiold et møde med enkelte medlemmer af forretningsudvalget, hvor man formulerede et forslag til bestyrelsen om at stille specialforbundene frit med hensyn til internationalt samarbejde. Den følgende dag viste Castenschiold det til kongen, der fandt det udmærket og klogt, og først derefter begav han sig til udenrigsministeriet, hvor direktør Mohr blev synligt lettet over udsigten til en ophævelse af beslutningen fra d. 15. april. Castenschiold var åbenbart temmelig sikker på, at bestyrelsen ville ophæve forbudet, for han aftalte med Eskelund, chef for udenrigsministeriets pressebureau, hvilken fremgangsmåde man skulle anvende for at informere offentligheden. Dette skulle gøres så stilfærdigt som muligt gennem udenrigsministeriets pressebureau, og det blev forbudt medierne at kommentere begivenheden. Hvorledes beslutningen ville blive modtaget af befolkningen, var den store usikkerhedsfaktor.

Bestyrelsesmødet d. 5. august foregik i en trykket stemning. Formanden redegjorde for de forskellige forhandlinger, og lagde ikke skjul på, at Renthe-Finks tålmodighed var på bristepunktet. Hvis det skulle være muligt 
for DIF fremover at føre en form for forhandlingspolitik, var tiden inde til at give Tyskland nogle radikale indrømmelser. Med hensyn til fremgangsmåden var det vigtigt, at de første arrangementer fandt sted mod andre nationer end Tyskland. Det ville derfor være passende, at man ventede med arrangementer med tysk deltagelse til efter fodboldlandskampen mod Sverige. Et enkelt medlem af bestyrelsen, Ernst Petersen, talte kraftigt imod en ophævelse, da det var det første skridt på vej væk fra DIFs selvstændighed, samtidigt med at det ville blive brugt til at vise omverden, at vi accepterede den tyske besættelse. Den fremherskende holdning var dog, at sagde DIF nej, ville det være slut med handle-friheden. Da man gik over til afstemning stemte 29 for en ophævelse, kun Ernst Petersen stemte imod.

,Det var, som når man slår vinduerne op i et forsamlingslokale, hvor der har været møde af alt for mange mennesker, eller som når man strækker lemmerne efter en god, sund søvn og føler livet vende tilbage. Overalt i idrætskredse drøftede man den pludseligt forandrede situation, og man drøftede den med smil om mund og glæde i sind.

Nu skal der tages fat!“

Således modtog Idrætsbladet DIFs beslutning. Endelig kom der gang i idrætslivet igen, og for bladet var der ingen tvivl om, at DIF havde truffet den rigtige beslutning. I samme nummer bragte man interviews med en række idrætsledere, der alle gav udtryk for et stærkt ønske om at få genoptaget det internationale samarbejde hurtigst muligt. Hovedparten nævnte Sverige og Tyskland som kommende modstandere, men også Norge og Finland stod højt på ønskeseddelen. Et gennemgående synspunkt var, at det rent sportsligt, og for at holde interessen for idræt ved lige, var nødvendigt at arrangere internationale idrætskampe, men at det også økonomisk var en nødvendighed, blev der ikke lagt skjul på for DBUs vedkommende.

Som tidligere beskrevet lagde både DIFs bestyrelse og udenrigsministeriet stor vægt på, at arrangementer med tysk deltagelse blev lagt efter den svensk-danske fodboldlandskamp, der skulle spilles d. 6. oktober. I praksis så man dog stort på dette inden for nogle idrætskredse, og den skepsis Castenschiold tidligere havde givet udtryk for, viste sig at være mere end berettiget. Visse forbund havde absolut ingen betænkeligheder ved straks at henvende sig til Tyskland for at få et samarbejde genetableret, og allerede d. 22. august 1940 løb det første internationale arrangement af stabelen i Danmark, ikke med svensk deltagelse, men med tysk.

Begivenheden var et atletikstævne på Østerbro Stadion i København, arrangeret af Københavns Atletik Forbund (KAF). Pressen gjorde meget ud af at beskrive idrætsudøvernes fremragende kvalifikationer, men kun „Fædre- 
landet" nævnte, ikke uden stolthed, at de tyske deltagere kom fra militærklubben, Luftwaffen Sportsverein-Berlin. Stævnet blev en stor succes både sportsligt og økonomisk, ikke mindre end 6000 mennesker gik gennem tælleapparaterne, hvilket også dengang var mange til et atletikarrangement. Besættelsesmagten undlod naturligvis ikke at vise flaget. Inden idrætskonkurrencerne underholdt et tysk militærorkester, og på tilskuerpladserne sad Renthe-Fink, generalløjtnant Lüdke samt flere fremtrædende personer fra DIF. Selve stævnet forløb tilfredsstillende for alle parter. DIFs bestyrelse og udenrigsministeriet kunne ånde lettet op, da deres frygt for publikumsdemonstrationer viste sig at være ubegrundet. Renthe-Fink kunne se med tilfredshed på den begejstring, de tyske løbere vakte hos det danske publikum, og desuden kunne han sende en udmærket film hjem til Berlin, der viste hvor strålende det hele var forløbet.

At KAF turde binde an med et sådant stævne, der åbenlyst var et brud med, hvad der var aftalt på DIFs bestyrelsesmøde d. 5. august, kan i første omgang virke overraskende, men ser man nærmere på forholdene omkring de ansvarlige for stævnet, forekommer det hele lidt mere logisk. Det har vist sig, at KAFs daværende formand Bøjesen-Barsøe nærede stærke nazistiske sympatier og blev arresteret umiddelbart efter besættelsen. Endvidere var formanden for KAFs hovedorganisation DAF, Svend Jensen, organiseret nazist. På baggrund af disse relationer er det forståeligt, hvorledes KAF var $\mathrm{i}$ stand til at stable et sådant arrangement på benene godt to uger efter, at der var givet grønt lys for en genoptagelse af det internationale idrætssamkvem.

Det næste arrangement med udenlandsk deltagelse var et dansk-tysk boksestævne, som ligeledes foregik i København. Også her strømmede publikum til, og Idrætsbladet karakteriserede det $i$ en stor overskrift som den største boksesucces i mange år. Der blev ikke sparet på ,,roserne" til de tyske boksere for deres fremragende tekniske standard. Igen en succes, både for det tyske gesandtskab og for de danske arrangører.

Udover de nævnte arrangementer deltog danske idrætsfolk $i$ en lang række konkurrencer med udlændinge i efteråret 1940, både på officielt og uofficielt plan, såvel i Danmark som i udlandet. Hovedsageligt foregik samarbejdet med idrætsfolk fra Sverige og Tyskland, men også andre lande, Finland og Norge, havde vi samkvem med dette år, selv om det var kvantitativt ubetydeligt $i$ forhold til de to førstnævnte lande.

Da idrætslivet var vendt tilbage til ",normale" tilstande, fungerede vort samarbejde med udlandet fortræffeligt de næste par år. Tages hele besættelsestiden i betragtning, toppede vort antal af landskampe i 1941 og 1942 med 18 kampe pr. år, hvilket kun var en lille del af det samlede internationale idrætssamkvem, da hovedparten af aktiviteterne foregik på lavere plan. Sammenlagt havde vi ni officielle landskampe mod Tyskland under besættel- 
sen, hvilket lå langt under antallet af landskampe mod Sverige, men fra tysk side har man åbenbart været tilfreds med dette antal, idet der i perioden mellem forbudets ophævelse og vinteren 1941-42 ikke blev rettet nogen henvendelser fra det tyske gesandskab til DIF som hovedforbund. Alle vore officielle landskampe mod Tyskland fandt sted $\mathrm{i}$ årene $1940 \mathrm{og} \mathrm{41.} \mathrm{Efter}$ årsskiftet 1941-42 var det kun Sverige, der fungerede som landskampmodstander. Det eneste dokumenterede samkvem vi havde med Tyskland efter 1941, var mod det tyske bokselandshold i sommeren 1942, men der var ikke tale om nogen officiel landskamp. Desuden deltog vi i bokse-krigseuropamesterskaberne i Tyskland januar 1942.

Fra tysk side gjorde man sig store anstrengelser, for at gøre et samarbejde så attraktivt som muligt. Ganske vist havde gesandtskabet visse pressionsmidler, såsom en skærpet ind- og udrejsetilladelses-politik, hvis det skulle vise sig, at nogen interesserede sig for meget for visse lande på bekostning af Tyskland. Dette var dog et middel man nødigt ville bruge, da det ville ødelægge effekten af et idrætssamarbejde. En måde at øge interessen hos specialforbund og foreninger for samkvem med Tyskland var, at tyskerne ydede pekuniær støtte til dækning af de udgifter, der var forbundet med idrætsstævner mellem de to lande. En metode der især tog sigte på de idrætsgrene, der ikke var vant til de store tilskuertal. Man inviterede danske hold på besøg i Tyskland med alt betalt, et tilbud som nogle foreninger benyttede sig af, selv om realiteterne ikke helt svarede til løfterne. Det kunne være svært at få dækket de udgifter, som tyskerne havde lovet. Under de danske idrætsfolks besøg i Tyskland, blev de behandlet fremragende. Målet var at give dem et positivt indtryk af Tyskland, og fra tysk side håbede man vel så, at dette gode indtryk ville sprede sig, når idrætsfolkene kom hjem og fortalte om deres oplevelser.

En anden måde at skabe good-will på for Tyskland var, at støtte de danske eliteidrætsfolk i deres bestræbelser på at blive bedre, gennem at stille tyske trænerkapaciteter til rådighed. Enten kom de tyske trænere her til landet, eller de danske idrætsfolk tog på længere træningsophold i Tyskland. Det tyske initiativ fik den forventede effekt, idet dele af den danske presse udtrykte stor begejstring over denne gestus fra tysk side. Der var endog enkelte danske idrætsfolk, der blev professionelle i Tyskland.

Sportsligt og økonomisk var vort internationale idrætssamkvem en succes. Vi opnåede udmærkede resultater, især når man tager de vanskelige træningsforhold $\mathrm{i}$ betragtning. Desuden strømmede tilskuerne til, når der var udenlandske idrætsfolk på programmet. De var næsten en garanti for publikumsucces. Fra pressens side sparede man ikke på reklametrommerne, når det gjaldt internationale stævner, og der var på ingen måde tale om, at man prøvede at fortie dansk-tyske idrætsarrangementer. Tværtimod blev der 
udtrykt stor begejstring for tyskernes idrætslige præstationer, og de blev ligefrem betegnet som fantastisk populære hos publikum.

Med hensyn til tilskuernes opførsel må den nærmest betegnes som upåklagelig, og efter pressens referater at dømme, fandt der en yderst ,fair“ behandling sted af de tyske idrætsfolk. Der er kun få eksempler på, at der har været uroligheder eller demonstrationer mod besættelsesmagten i forbindelse med idrætskampe. Det mest omtalte eksempel på uroligheder ved en idrætsbegivenhed er fodboldkampen i Idrætsparken d. 5. juli 1941 mellem wienerholdet „Admira“ og et udvalgt københavnsk hold. Under kampen havde tilskuerne piftet lidt da ,Admira“ brugte den nazistiske hilsen, og enkelte tilskuere havde generet nogle tyske soldater. Efter kampen kom det til et mindre håndgemæng mellem nogle danskere og tyske soldater, men efter politiets rapporter var der kun tale om en mindre batalje. Uanset hvor ubetydelig episoden forekommer, fik den alvorlige politiske konsekvenser, da den medførte justitsminister Harald Petersens afsked. Urolighederne var imidlertid ikke årsagen til dette. Renthe-Fink havde længe ment, at politiet ikke greb energisk nok ind over for befolkningens demonstrationslyst, og urolighederne ved ,Admira"-kampen blev anledningen, der kunne bruges til at få justitsministeren fjernet fra sin post.

Generelt må det konkluderes, at tilskuernes opførsel ved idrætsarrangementer i årene 1940 og 1941, ikke adskilte sig væsentligt fra gængse normer ved sådanne lejligheder. Der var på ingen måde tale om nogen form for publikumsboycot af stævner med tysk deltagelse, tværtimod strømmede folk til, mange dog sikkert med den forhåbning, at de tyske idrætsfolk ville få en ordentlig en på ,tærven“.

Ophævelsen af forbudet mod idrætssamkvem blev modtaget med tilfredshed inden for størstedelen af idrætsbevægelsen, både af sportslige og økonomiske grunde. Det lå i luften, at det var nødvendigt med internationalt samkvem, hvis eliteidrætten skulle fungere på hjemmefronten. Ganske vist var det først og fremmest Sverige, man ønskede at samarbejde med, men alle var klar over, at hvis dette skulle blive en realitet, var det nødvendigt også at samarbejde med Tyskland. Dette forhold vakte ikke større bekymring i idrættens ledende kredse; samarbejdet med Tyskland blev ikke betragtet som nogen større belastning i de første år af besættelsen. Det var ikke almindeligt, at man prøvede at undgå tyske idrætsfolk, eller trække tiden ud, når man forhandlede om kommende kampdatoer.

I idrætskredse var der bred enighed om, at man endelig skulle bestræbe sig på ikke at komme i modsætningsforhold til Tyskland. Urolighederne ved „Admira“-kampen bragte derfor DBU i en meget ubehagelig situation, selv om forbundet ikke bar nogen direkte skyld for episoden. Inden for DBU var man synligt bange for, at urolighederne ville skade fodboldsamarbejdet med 
udlandet, og Leo Frederiksen skyndte sig at sende en lang skriftlig undskyldning til Renthe-Fink. Heri angreb han urostifterne i meget kraftige vendinger, hvilket han ligeledes gjorde $i$ en meddelelse til pressen. Inden meddelelsen blev overgivet pressen, var den til godkendelse i udenrigsministeriet, som strøg flere passager, bl.a. de værste angreb på urostifterne, således at meddelelsen fremstod betydelig mere neutral, end den havde gjort i DBUs oprindelige udformning.

Et andet eksempel på, hvor påpasselige man var for ikke at provokere besættelsesmagten, findes inden for boksningen. En dansk boksedommer, Marius Sick, der ansøgte om at få sin dommerlicens tilbage efter sin internering $\mathrm{i}$ oktober 1942, blev nægtet dette af DABUs forretningsudvalg med den begrundelse, at unionen ikke ville virke provokerende. Senere på året lykkedes det ham alligevel at få licensen tilbage, men DABU henstillede til sine klubber, at de benyttede Marius Sick så lidt som muligt.

De to anførte eksempler kan naturligvis ikke opfattes som værende umiddelbart gyldige for hele idrættens opfattelse af situationen, men de er med til at antyde hvilke midler, der blev anvendt - og hvor langt man ville gå for ikke at komme $i$ et dårligt forhold til besættelsesmagten. Ikke fordi man specielt var interesserede $i$ et samarbejde med Tyskland, men fordi et godt forhold blev betragtet som en forudsætning for, at idrætten kunne fungere nogenlunde som før d. 9. april. At man måske også frygtede en direkte nazistisk indblanding i dansk idræt, kan ikke udelukkes, da der faktisk eksisterede planer om en dansk nazistisk overtagelse af idrætten, gennem Danmarks Nationalsocialistiske Idrætsgruppe. Dette var dog ikke noget, man åbenlyst diskuterede i DIFs bestyrelse. Måske stolede man ikke på alle bestyrelsesmedlemmerne.

Et væsentligt aspekt omkring hele problematikken om samkvem med Tyskland er, hvorledes de "menige" aktive idrætsudøvere forholdt sig til at skulle konkurrere med tyskere. Desværre er materialet omkring dette punkt meget mangelfuldt. Ernst Petersen påstod i sommeren 1940, at idrætsudøverne på Fyn ikke ønskede at konkurrere mod tyske tropper. På den anden side må det fremhæves, at der øjensynligt ikke har været nogen større problemer med at få idrætsfolk til at stille op i konkurrencer mod tyskere i begyndelsen, og først senere, hvor der kan spores en begyndende holdningsændring i befolkningen, er der tegn på et usikkerhedsmoment omkring idrætsfolkenes holdning. Jeg har ikke fundet nogen eksempler på, at idrætsfolk har nægtet at stille op, men DIFs beslutning i vinteren 1941-42 om i realiteten at standse samkvemmet med Tyskland (se senere), gjorde også dette forhold uaktuelt på et forholdsvis tidligt tidspunkt.

Som det er fremgået, betragtede de danske tilskuere hovedsageligt de tyske idrætsfolk som idrætsfolk, og ikke som repræsentanter for en nazistisk 
undertrykkelsesmagt. Et synspunkt som fodboldspilleren Knud Lundberg, der deltog i kampen mod ,Admira“, også gav udtryk for:

„,Vi var mange, der diskuterede før matchen, om vores modstandere nu var nazister - eller følte det samme over for en tysk besættelse som vi.

Det endte med, at vi blev enige om at betragte dem som fodboldspillere - vist et ganske fornuftigt standpunkt".

Udtalelsen skal naturligvis tages med et vist forbehold, da det var et østrigsk hold, det drejede sig om. Det centrale i denne forbindelse er dog opfattelsen af østrigerne som fodboldspillere, ikke som repræsentanter for en politisk ideologi, selv om de bl.a. brugte den nazistiske hilsen.

For at samarbejdet med udlandet kunne glide så konfliktløst som muligt, var det fra begyndelsen meningen, at samarbejdet skulle ledes fra centralt hold, helt præcist af Castenschiold selv. Dette viste sig hurtigt umuligt på grund af selvstændige initiativer fra visse forbund og foreninger. DIFs øverste ledelse gjorde umiddelbart ikke noget for at få denne centralisering gennemført, da den først var gledet ud af hænderne på den.

I sidste halvdel af 1941 begyndte man at kunne spore en vis ændring i den danske befolknings holdning. Der noteredes et stigende antal episoder, hvor tyske soldater følte sig forulempet, og mange var for alvor begyndt at tvivle på forhandlingspolitikkens rigtighed. De danske kommunister var ,gået under jorden" efter d. 22. juni 1941, og ikke kun her, men også andre steder, var der efterhånden skabt grobund for illegalt arbejde. I de danske radioudsendelser fra BBC i London, opfordrede man i vinteren 1941 de danske idrætsudøvere til at afholde sig fra at deltage i konkurrencer med tyskere, og tage ved lære af de norske idrætsfolk.

For idrætten betød de ændrede forhold en realistisk risiko for, at arrangementer med tysk deltagelse kunne føre til demonstrationer fra publikums side, evt. også fra de aktives. Disse forhold kunne ikke undgå at påvirke DIFs politik, og i begyndelsen af 1942 erkendte forretningsudvalget også, at en central styring af idrætsarbejdet var nødvendig. Bagtanken med denne styring var at nedskære samkvemmet med Tyskland til et minimum, mens man stadig ville forsøge at opretholde det med Sverige. Denne styring lykkedes fint, det dansk-tyske klub- og unionssamarbejde standsede i det store og hele, og på landskampniveau var det kun Sverige vi mødtes med efter 1941. Dette betød ikke, at man havde afskrevet Tyskland som landskampmodstander, DABU aftalte sommeren 1942 en landskamp med Tyskland, der efter planen skulle afvikles i København februar 1943. Kampen blev aldrig afholdt, da det tyske hold sendte afbud i sidste øjeblik. Landskampsamarbejdet med Sverige fortsatte frem til d. 29. august 1943, hvor den 
danske regering gik af, og overlod roret til det såkaldte departementschefstyre. Det lykkedes dog at få en enkelt landskamp gennemført efter denne dato.

Fra tysk side skærpede man bestemmelserne om ind- og udrejsetilladelser i sidste halvdel af 1941. Denne skærpelse medførte, at enkelte planlagte kampe mod svenske hold måtte aflyses, og ligeledes forekom det at tyske hold sendte afbud til kampe i Danmark. Den stemning af fordragelighed, der havde præget det dansk-tyske idrætsforhold siden august 1940, forsvandt i løbet af 1941, og urolighederne omkring „Admira"-kampen kan betegnes som begyndelsen på denne udvikling. Vinteren 1941-42 indgik de tyske myndigheder og DIF en aftale omkring ind- og udrejsetilladelser samt andre forhold omkring vort samarbejde med Tyskland. Aftalen var baseret på et større hensyn til Tyskland, hvilket uden tvivl betød, at det dansk-svenske samkvem skulle begrænses. DIFs forretningsudvalg opfattede imidlertid kun aftalen som retningsgivende, man ville ikke pålægge specialforbundene nogen forbud ud fra den. På den anden side kunne man heller ikke se helt bort fra den, og forretningsudvalget blev $i$ enkelte tilfælde nødt til at give afslag på ansøgninger vedrørende idrætssamkvem med Sverige. Dette er uden tvivl sket ud fra det synspunkt, at det gavnede helheden bedst at vise sin gode vilje til at efterkomme de tyske ønsker, og at en tilsidesættelse af aftalen ville medføre endnu strengere krav og indgreb fra tysk side.

På baggrund af de ting, der begyndte at røre sig i befolkningen, er det ikke så underligt, at tyskerne mistede den store interesse for idrætssamarbejdet vinteren 1941-42. Hvis de dansk-tyske idrætsarrangementer udviklede sig til demonstrationer mod besættelsesmagten, havde de ikke længere nogen værdi, tværtimod ville de være en yderligere ophidselsesfaktor mod Tyskland.

Det bemærkelsesværdige er, at man fra tysk side tillod Danmark et så udstrakt samarbejde med Sverige, efter at det dansk-tyske reelt var standset. Selv om der var problemer med at opnå de diverse tilladelser, blev der ikke gjort noget forsøg på fra tysk side at standse samkvemmet helt før d. 29. august 1943. Man må åbenbart have anset et forbud mod disse arrangementer som en uhensigtsmæssig handling, der kun yderligere ville ophidse den danske befolkning.

I juli måned 1942 blev DIF kontaktet af det tyske idrætsforbund. Anledningen var, at Tyskland havde besluttet at reorganisere den europæiske idrætsstruktur, således at idrætten blev samlet i et europæisk sports-forbund under tysk ledelse. DIF gjorde sig store anstrengelser for at undgå at deltage, men blev presset, bl.a. af det danske udenrigsministerium, til at deltage $i$ et indledende møde. Der var flere årsager til, at DIF ikke ønskede at deltage $\mathrm{i}$ stiftelsen af det nye forbund. Dels ville man på dette tidspunkt undgå samarbejde med det nazistisk styrede norske idrætsforbund, dels mente 
man, at det var en politisk handling fra tysk side. DIFs nye formand, oberst $\mathrm{H}$. Sander, var af den opfattelse, at en tilslutning sandsynligvis ville blive opfattet af befolkningen som en politisk stillingtagen, hvilket ville medføre en splittelse af idrætsbevægelsen. Han havde sikkert urolighederne ved Danmarks tilslutning til Antikominternpagten året før i frisk erindring, og på baggrund af befolkningens stigende modstandsvilje over for besættelsesmagten var Sanders konklusion fuldt forståelig. Det forhold DIF imidlertid lagde mest vægt på, var svenskernes holdning, og de ville under ingen opstændigheder deltage. På baggrund af dette valgte DIF at sende afbud til konferencen, og sagen døde hen uden yderligere tyske henvendelser, hvilket sandsynligvis hang sammen med krigens ugunstige udvikling for Tyskland.

Forhandlingerne omkring sportsforbundet var den sidste direkte kontakt, DIF havde med besættelsesmagten under krigen. Ved en sammenligning af dette forhandlingsforløb med de begivenheder, der fandt sted sommeren 1940 under forhandlingerne mellem DIF, besættelsesmagten og det danske udenrigsministerium, er der flere afgørende forskelle, som springer i øjnene. Lige fra DIF tog beslutningen om at standse samarbejde med udlandet d. 15. april 1940 og indtil forbudets ophævelse i august samme år, lagde DIFs daværende formand stor vægt på at konsultere udenrigsministeriet for at få gode råd, og få sikkerhed for at DIF havde ministeriets samtykke til dets beslutninger. Ved forhandlingerne 1942 var lige det modsatte tilfældet, DIFs formand var absolut ikke interesseret $i$, at udenrigsministeriet blev involveret i sagen. Ministeriet fik intet at vide om hvad der foregik, udover de informationer som det kunne indhente fra det tyske gesandtskab. Det var ikke ministeriets vejledning, Sander lagde til grund for DIFs endelige beslutning, men derimod hvorledes Sverige mente, at man skulle forholde sig. Forskellen på de to forløb skyldtes ikke, at der var sket et formandsskifte i DIF, men derimod den politiske udvikling, der var karakteriseret ved den ene danske indrømmelse efter den anden til tyskerne fulgt af en aftagende opbakning fra befolkningen til denne politik. Det viste sig også, at udenrigsministeriet ikke ville støtte DIFs holdning, man var absolut ikke interesseret $i$ endnu en konflikt.

For DIF var idræt en upolitisk foreteelse, og derfor lå der en bevidst neutral stillingtaǵen i beslutningen om idrætssamkvemmet med Tyskland. Forbundet lukkede så vidt muligt øjnene for de propagandamuligheder, der i nazismens ånd kunne komme til udtryk gennem idrætten. Man så ingen fare ved at tyske idrætsfolks dygtighed kunne virke imponerende på den almene danske borger, og at der gennem denne glorificering kunne skabes grobund for nazismen.

Selve DIFs politik under besættelsen er en nøje afspejling af befolkningens holdning til den danske regerings politik over for Tyskland. Tilskuernes 
modtagelse af og reaktion ved de dansk-tyske idrætsstævner kan kun bekræfte den opfattelse, at der i den første periode af besættelsen absolut ikke var noget ønske fra befolkningen om at indføre „norske tilstande“ i Danmark, lige så lidt som dette var tilfældet for DIFs vedkommende. 